\title{
Spectroelectrochemical Study of Stainless Steel Corrosion in NaCl-KCl Melt
}

\author{
A.V. Abramov, ${ }^{a}$ I.B. Polovov, ${ }^{a}$ V.A. Volkovich, ${ }^{a}$ O.I. Rebrin,,${ }^{a}$ T.R. Griffiths, ${ }^{b}$ \\ I. May, ${ }^{\mathrm{c}}$ H. Kinoshita ${ }^{\mathrm{c}}$ \\ a Department of Rare Metals and Nanomaterials, Ural Federal University, Ekaterinburg, \\ 620002, Russia \\ ${ }^{\mathrm{b}}$ Redston Trevor Consulting, Ltd., Leeds, LS17 8RF, UK \\ ${ }^{\mathrm{c}}$ The Centre for Radiochemistry Research, The University of Manchester, Manchester, \\ M13 9PL, UK
}

\begin{abstract}
High-temperature spectroelectrochemestry was applied to study corrosion of various types of stainless steel in molten salts. The electronic absorption spectra of products of anodic dissolution of stainless steel major components (iron, chromium, nickel, molybdenum, manganese, titanium) were measured in $\mathrm{NaCl}-\mathrm{KCl}$ melt at $750{ }^{\circ} \mathrm{C}$. The effectiveness and limitations of applying spectroscopic method for studying alloys corrosion was demonstrated on example of anodic dissolution of AISI 316L, $316 \mathrm{Ti}$ and 321 austenitic steels. The major corrosion products of steels are iron, manganese and chromium species. Prolongation of anodic dissolution leads to increasing chromium-to-iron ratio in the melt. Titanium in steels forms very stable carbonitride species that aren't dissolved during anodic oxidation.
\end{abstract}

\section{Introduction}

Understanding corrosion of individual metals and alloys in molten salts is very important for developing new technologies of rare and refractory metals production and pyrochemical reprocessing of spent nuclear fuels in fused halide media. The corrosion of several types of stainless steel in different chloride melts have been investigated by a number of research groups, but there is no single point of view concerning the mechanism of stainless steel corrosion in halide melts (1-21). It is generally accepted, that in oxidizing environment a so-called dechromization process (selective leaching of chromium species) takes place during the exposure of steels to molten salts. In recent studies it was shown, that chromium(III) oxide $\mathrm{Cr}_{2} \mathrm{O}_{3}$ formed is highly soluble in molten chlorides forming chromate-ions and chlorine, dissolved in the electrolyte, and thus enhancing the degradation of steel (18-21). However, the data concerning corrosion of stainless steels in molten chlorides under inert atmosphere are limited and poor, and the mechanism of processes is still not understood. The corrosion rates of stainless steels in chloride melts under argon atmosphere are much lower than in air, indicating different causes and mechanisms of the corrosion processes (13). Moreover, contacting alloy samples with molten salt under an inert atmosphere resulted in the samples weight decrease accompanied by intergranular corrosion (12). It was also noted that steel components were initially dissolving in the melt in the same ratio in which they were present in the steel. The increase of exposure time to over $1000 \mathrm{~h}$ led to selective enrichment of melt in chromium as the most electronegative steel component (12). 
Electrochemical and gravimetric methods are most commonly employed to study the corrosion process. In the present work we used in situ high temperature electronic absorption spectroscopy measurements to identify the corrosion products of metals and alloys. Metal corrosion in molten salts under inert atmosphere is electrochemical in nature and anodic dissolution was used here to facilitate the process studied. Spectroscopic investigation of stainless steel anodic dissolution in alkali chloride melts allows determining the sequence in which its components are dissolved. To interpret the obtained results the recorded spectra were compared with the absorption spectra of the melts containing the products of anodic dissolution of pure metals constituting the stainless steels studied.

\section{Experimental}

The electronic absorption spectra (EAS) were recorded between 200 and $1500 \mathrm{~nm}$ using an original set-up based on Avantes AvaSpec-2048-2 and NIR256-1.7 fiber optic spectrometers. All experiments were performed in $\mathrm{NaCl}-\mathrm{KCl}$ equimolar melt at $750{ }^{\circ} \mathrm{C}$. The experimental techniques of spectroscopic measurements during anodic dissolution in molten salts and design of spectroelectrochemical cells have been described previously (22). Anodic current density was set bellow $10 \mathrm{~mA} / \mathrm{cm}^{2}$, and the time of dissolution was varied depending on the molar absorption coefficients of the elements studied. At the first stage of the work the anodic dissolution of a number of individual elements representing the major components of stainless steels was studied and the EAS of iron, chromium, nickel, molybdenum, manganese and titanium chloro-species were recorded.

In a separate series of experiments the processes of anodic dissolution of AISI321, AISI316Ti and AISI316L types of steel were investigated. Chemical composition of studied stainless steels is given in Table I. The experiments were conducted in the same manner as with individual metals. The anodic current was $20 \mathrm{~mA}$. EAS were recorded at certain time intervals. The entire time of anodic dissolution varied from 8 to $125 \mathrm{~min}$.

TABLE I. Chemical composition of studied stainless steels.

\begin{tabular}{ccccccccccc}
\hline Type of & \multicolumn{10}{c}{ Component content, wt. \% } \\
steel & $\mathbf{C}$ & $\mathbf{S i}$ & $\mathbf{M n}$ & $\mathbf{C r}$ & $\mathbf{N i}$ & $\mathbf{T i}$ & $\mathbf{M o}$ & $\mathbf{S}$ & $\mathbf{P}$ & $\mathbf{C u}$ \\
\hline AISI 316L & $<0.03$ & $<0.4$ & $1.0-2.0$ & $16.8-18.3$ & $13.5-15.0$ & - & $2.2-2.8$ & 0.02 & 0.03 & - \\
AISI 316Ti & $<0.1$ & $<0.8$ & $<2.0$ & $16.0-18.0$ & $12.0-14.0$ & $0.5-0.7$ & $2.0-3.0$ & 0.02 & 0.035 & 0.3 \\
AISI 321 & $<0.12$ & $<0.8$ & $<2.0$ & $17.0-19.0$ & $9.0-11.0$ & $0.5-0.8$ & - & 0.02 & 0.035 & 0.3 \\
\hline
\end{tabular}

Quenched melt samples taken after each experiment were analyzed to determine the content of the elements of interest using ICP MS method (Elan 9000, Perkin Elmer) and X-ray fluorescence spectroscopy (ARL QUANT'X). The surface of steel samples after anodic dissolution was examined using metallographic analysis (Olympus GX-71F) and X-ray microanalysis (JSM 6490).

\section{Results and discussion}

$\underline{\text { Anodic dissolution of individual metals }}$

The EAS of the melts obtained after anodic dissolution of studied metals in $\mathrm{NaCl}-\mathrm{KCl}$ melt at $750{ }^{\circ} \mathrm{C}$ are presented in Figure 1. Average oxidation state of the metals was determined in quenched melt samples from the results of the red-ox titration (23). Using 
these data and comparing the measured spectra with published in the literature $(24,25)$ we can conclude that nickel(II), chromium(II), molybdenum(III), manganese(II) and titanium(III) species were formed. There are no maxima in EAS measured during anodic dissolution of iron (Figure 1a). However, chemical analysis confirmed that iron(II) species were present in the electrolyte. Thus the absorption peak of the expected ${ }^{5} \mathrm{E} \rightarrow{ }^{5} \mathrm{~T}_{2}$ electronic transition in $\mathrm{FeCl}_{4}{ }^{2-}$ complex ( $d^{6}$-configuration) lies above $1500 \mathrm{~nm}$.

a

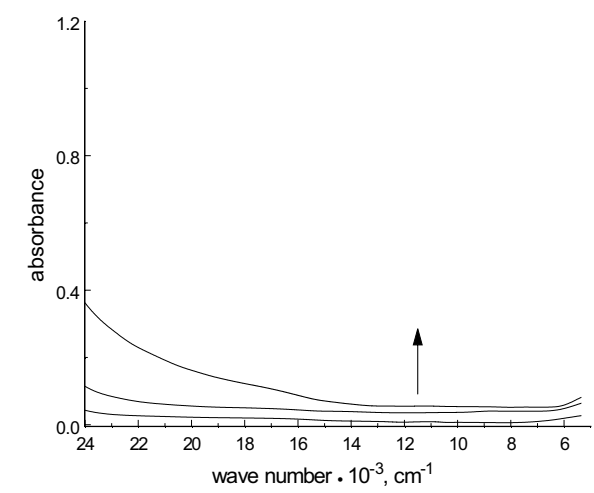

c

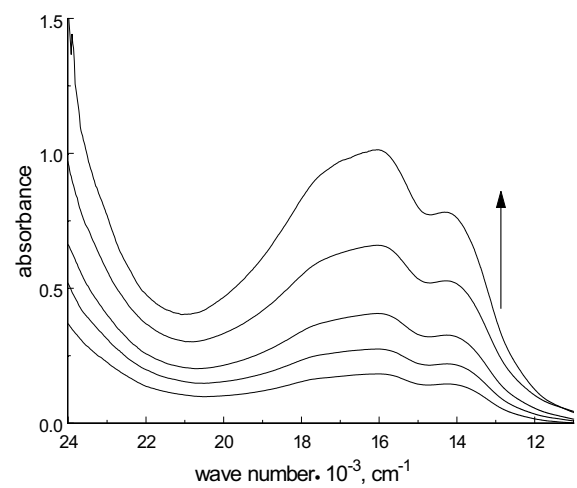

e

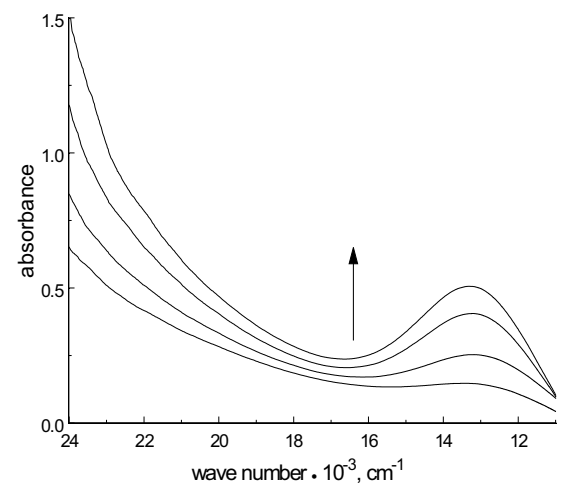

b

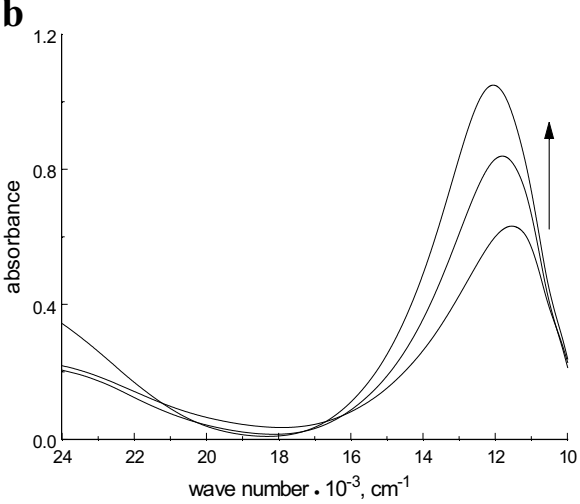

d

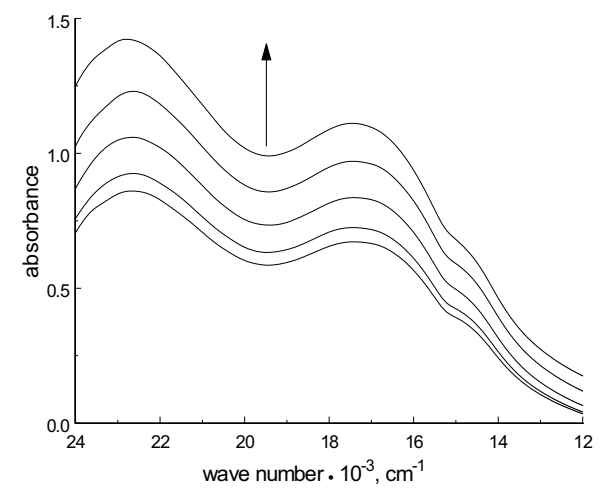

f

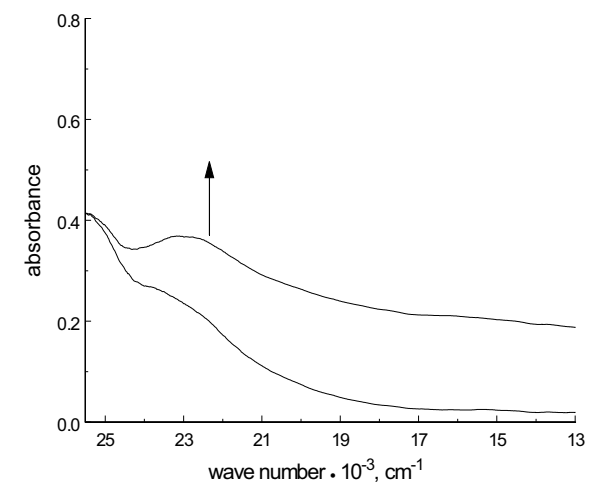

Figure 1. Electronic absorption spectra recorded during anodic dissolution of major stainless steel constituents in $\mathrm{NaCl}-\mathrm{KCl}$ melt at $750{ }^{\circ} \mathrm{C}$ : a - iron, b - chromium, $\mathrm{c}$ - nickel, $\mathrm{d}$ - molybdenum, $\mathrm{e}$ - titanium, $\mathrm{f}$ - manganese. Arrows indicate the direction spectra changed. 
The positions of major bands are summarized in Table II. Analysis of the spectra showed that the anodic dissolution of iron, chromium, nickel, molybdenum, manganese and titanium in $\mathrm{NaCl}-\mathrm{KCl}$ melt at $750{ }^{0} \mathrm{C}$ mainly led to the formation of the corresponding complex ions: $\mathrm{CrCl}_{4}{ }^{2-}, \mathrm{NiCl}_{4}{ }^{2-}, \mathrm{MoCl}_{6}{ }^{3-}, \mathrm{MnCl}_{4}{ }^{2-}$ and $\mathrm{TiCl}_{4}{ }^{-}$.

TABLE II. Positions of the absorption bands in EAS of chloro-complexes of stainless steel components

\begin{tabular}{cc}
\hline Complex & Absorption bands of stainless steal components, $\mathbf{~ c m}^{-1}$ \\
\hline $\mathrm{FeCl}_{4}^{2-}$ & $<6700$ \\
$\mathrm{CrCl}_{4}^{2-}$ & 12200 \\
$\mathrm{NiCl}_{4}^{2-}$ & $14100,16000,17600$ \\
$\mathrm{MoCl}_{6}^{3-}$ & 14800,17300 \\
$\mathrm{MnCl}_{4}^{2-}$ & 23000 \\
$\mathrm{TiCl}_{6}^{3-}$ & 13300 \\
\hline
\end{tabular}

$\underline{\text { Anodic dissolution of stainless steels }}$

Data on anodic dissolution of studied metals were used to identify the corrosion products of stainless steels and order of their appearance in the melt during anodic dissolution. A spectroscopic study of the anodic dissolution of AISI321, AISI316Ti and AISI316L stainless steels revealed that the process always leads to the formation of chromium $\mathrm{CrCl}_{4}^{2-}$ complex ions (Figure 2). Chemical analysis of the quenched melt samples also showed the presence of iron and manganese (Table III). It is likely that manganese, as the most electronegative element in the steel, was one of the first components to dissolve but the absorption maximum of $\mathrm{MnCl}_{4}{ }^{2-}$ at $23000 \mathrm{~cm}^{-1}$ was masked by the charge transfer bands of iron and chromium. Analysis of quenched melts also showed that iron dissolved to a large extent. No absorption bands corresponding to $\mathrm{FeCl}_{4}{ }^{2-}$ were observed because their maximum lies in the near infrared region (bellow $6700 \mathrm{~cm}^{-1}$ ). Thus on the basis of the spectral data alone we cannot draw a conclusion concerning preferable dissolution order of the above mentioned elements. However, the absence of absorption peaks of $\mathrm{MoCl}_{6}{ }^{3-}, \mathrm{NiCl}_{4}{ }^{2-}, \mathrm{TiCl}_{6}{ }^{3-}$ complex ions indicates that these elements do not transfer to the electrolyte during anodic dissolution of the steel. This was also confirmed by the results of the chemical analysis of melt samples. From the electrochemistry point of view, the fact that electropositive nickel (26) and molybdenum (27) remain in the anode material points out to the electrochemical nature of the corrosion process. The results of the spectroscopy measurements and chemical analysis were confirmed by X-ray microanalysis - the surface of electrode after $2 \mathrm{~h}$ of anodic dissolution was slightly depleted in iron and chromium, and was enriched in nickel.

At the same time the fact that titanium remains undissolved in the anode material cannot be explained by the electrochemical reasons, because formal standard potential of titanium is more negative than of other steel components (except for manganese) (27). It is well known, that addition of titanium to steels prevents chromium carbide formation due to strong interaction of titanium with carbon (28). When metallographic analysis was carried out, the grains of other phase were noticed in the bulk of AISI 321 and 316Ti (Figure 3). According to the micro X-ray analysis these grains consist of 53-65 wt. \% Ti, $12-16$ wt. $\% \mathrm{C}, 18-25 \% \mathrm{~N}$. It can be concluded that titanium in steels is associated with carbon and nitrogen forming carbonitrides, and this likely prevented titanium dissolution.

The surface of the steel samples after anodic dissolution was flat and smooth (Figure 4). There was no indication of intergranular corrosion. 
a

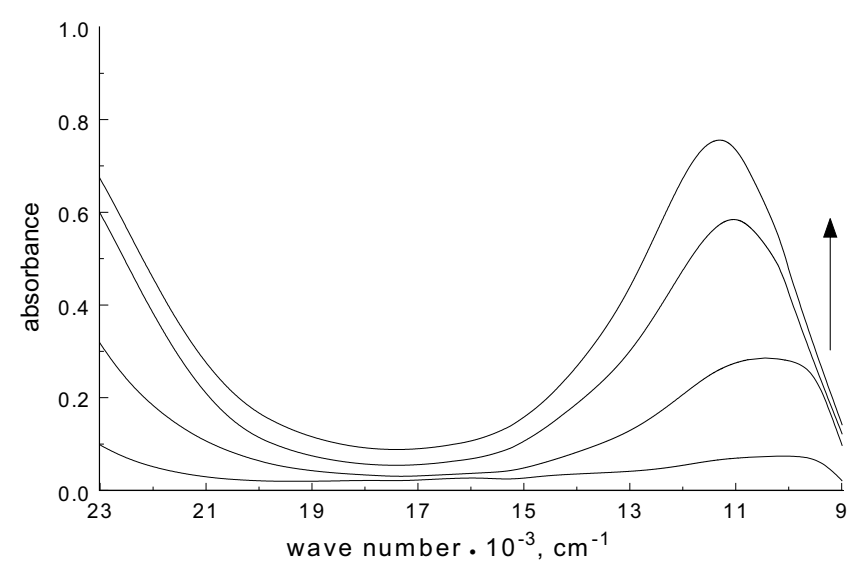

b

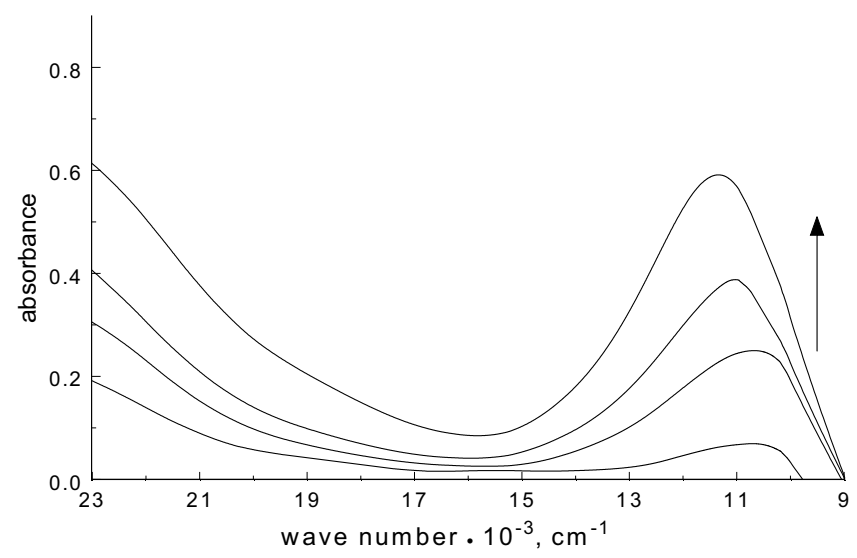

c

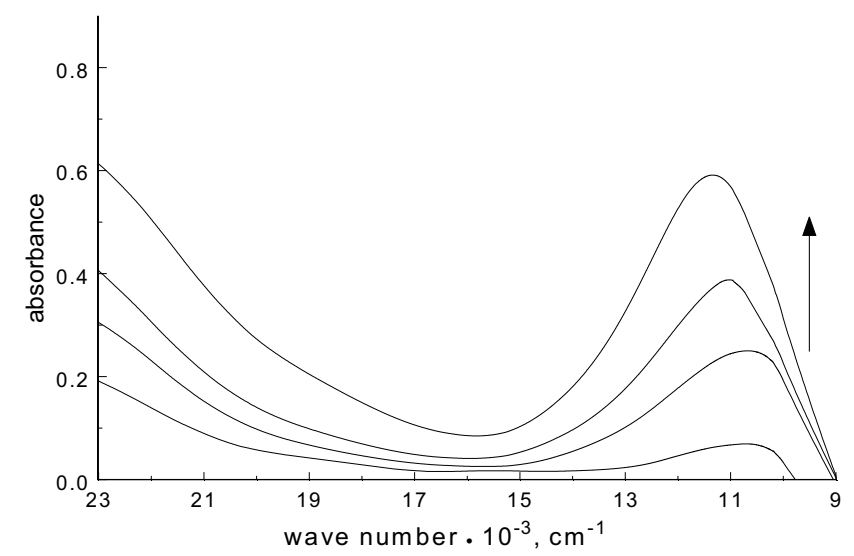

Figure 2. Spectral curves measured during anodic dissolution of AISI 321 (a), AISI 316Ti (b) and AISI 316L steels in $\mathrm{NaCl}-\mathrm{KCl}$ at $750{ }^{\circ} \mathrm{C}$. Arrows indicate the direction spectra changed.

A series of electrochemical experiments was conducted in which the period of AISI $316 \mathrm{~L}$ anodic dissolution in $\mathrm{NaCl}-\mathrm{KCl}$ at $750{ }^{\circ} \mathrm{C}$ was varied from 8 to $125 \mathrm{~min}$. to monitor 
possible changes of stainless steel components content. The results obtained are presented in Table IV. It can be seen that the major elements present in the melt are iron, chromium and manganese. During the initial period of time the concentration of iron in the electrolyte was higher, than chromium compared to their concentration in the steel (Figure 5). Prolonged anodic dissolution of steel samples resulted in increasing chromium-to-iron ratio in the melt, and after 2 hours the $\mathrm{Cr}: \mathrm{Fe}$ ratio in the melt exceeded that in the steel. This fact agrees well with the results of spectroelectrochemichal experiments. At the same time the value of manganese-to-iron content remained essentially constant and close to the initial content ratio in the steel.

TABLE III. Chemical analysis of quenched melts after anodic dissolution of stainless steels in $\mathrm{NaCl}-\mathrm{KCl}$ at $750{ }^{\circ} \mathrm{C}$

\begin{tabular}{|c|c|c|c|c|c|c|}
\hline \multirow{2}{*}{ Type of steel } & \multicolumn{6}{|c|}{ Component content, wt. \% / h } \\
\hline & $\mathrm{Fe}$ & $\mathrm{Cr}$ & $\mathrm{Ni}$ & Mo & $\mathbf{T i}$ & Mn \\
\hline AISI 316L & 0.4048 & 0.0691 & 0.0010 & 0.0001 & $<0.0001$ & 0.0069 \\
\hline AISI 316Ti & 0.4328 & 0.0903 & $<0.0001$ & 0.0001 & $<0.0001$ & 0.0102 \\
\hline AISI 321 & 0.4848 & 0.1578 & 0.0008 & 0.0001 & $<0.0001$ & 0.0191 \\
\hline
\end{tabular}

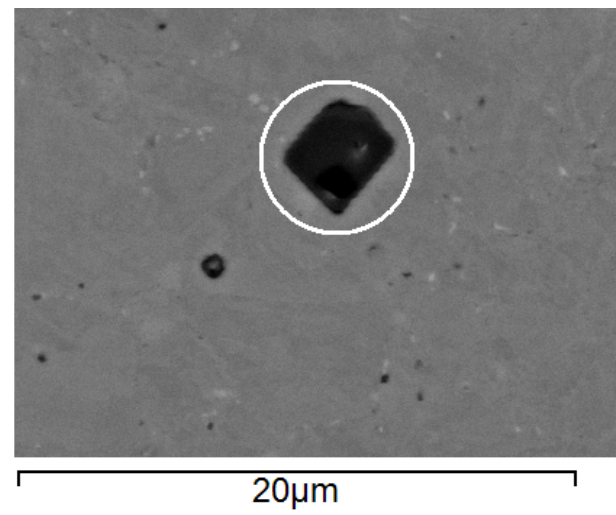

Figure 3. The bulk of AISI 316Ti with titanium carbonitride grain.

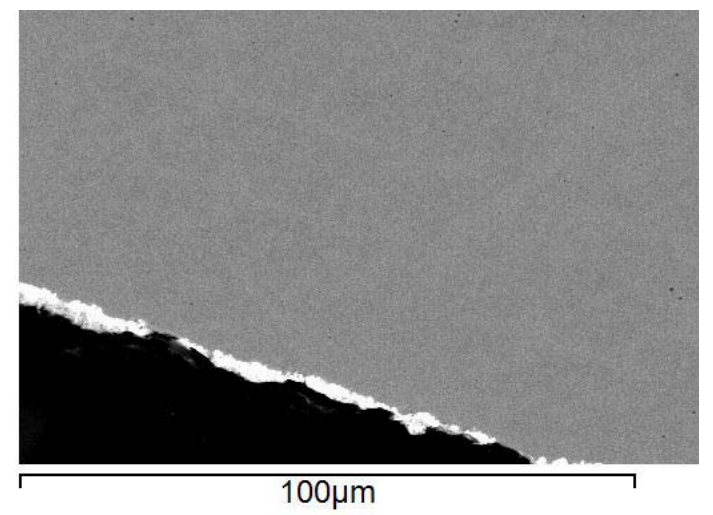

Figure 4. The surface of AISI 316L steel after anodic dissolution in $\mathrm{NaCl}-\mathrm{KCl}$ at 750 ${ }^{0} \mathrm{C}$ (time of dissolution - $125 \mathrm{~min}$, current $20 \mathrm{~mA})$.

TABLE IV. Stainless steel component content in quenched electrolyte samples after anodic dissolution of AISI $316 \mathrm{~L}$ alloy in $\mathrm{NaCl}-\mathrm{KCl}, 750^{\circ} \mathrm{C}$

\begin{tabular}{|c|c|c|c|c|c|c|}
\hline \multirow{2}{*}{$\begin{array}{c}\text { Time of } \\
\text { dissolution, } \min \end{array}$} & \multicolumn{6}{|c|}{ Component content, wt. \% } \\
\hline & $\mathbf{F e}$ & $\mathrm{Cr}$ & $\mathbf{N i}$ & Mo & Ti & Mn \\
\hline 8 & 0.08 & 0.015 & 0.0001 & $<0.0001$ & $<0.0001$ & 0.003 \\
\hline 17 & 0.15 & 0.029 & 0.0001 & $<0.0001$ & $<0.0001$ & 0.006 \\
\hline 36 & 0.28 & 0.036 & 0.0001 & $<0.0001$ & $<0.0001$ & 0.011 \\
\hline 85 & 0.48 & 0.073 & 0.0002 & $<0.0001$ & $<0.0001$ & 0.020 \\
\hline 125 & 0.90 & 0.248 & 0.0001 & $<0.0001$ & $<0.0001$ & 0.030 \\
\hline
\end{tabular}

To explain the observed results the quantity of electricity passed through the cell $\left(Q_{\text {passed }}\right)$ and the formal quantity of electricity required for the dissolution of determined content of iron, chromium and manganese $\left(\mathrm{Q}_{\text {dissolved }}\right)$ were calculated. The results showed that in the beginning of the dissolution the amount of the metal species in the melt was noticeably higher than the expected amount associated with the quantity of electricity passed, Figure 6. Taking into account a well-known mechanism of corrosion of the individual metals under an inert atmosphere based on the exchange reactions we can conclude that during the initial period of dissolution the reaction of steel components with 
the alkali metal cations present in the melt plays an important role in the corrosion process $(4,29,30)$. Iron, as a major component of the steel, predominately dissolves at the first stage of corrosion according to the following reaction:

$$
\mathrm{Fe}_{(\text {steel })}+2 \mathrm{Me}^{+}{ }_{\text {(melt) }}=\mathrm{Fe}^{2+}{ }_{(\text {melt })}+2 \mathrm{Me}_{(\text {melt })}
$$

where $\mathrm{Me}^{+}=\mathrm{Na}^{+}$and $\mathrm{K}^{+}$. The reaction of alkali metal cations with other steel constituents is also possible but owing to their lower content in the steel and strong interaction between the components in Fe-Cr-Ni alloys the dissolution of elements other than iron by such mechanism is less noticeable.

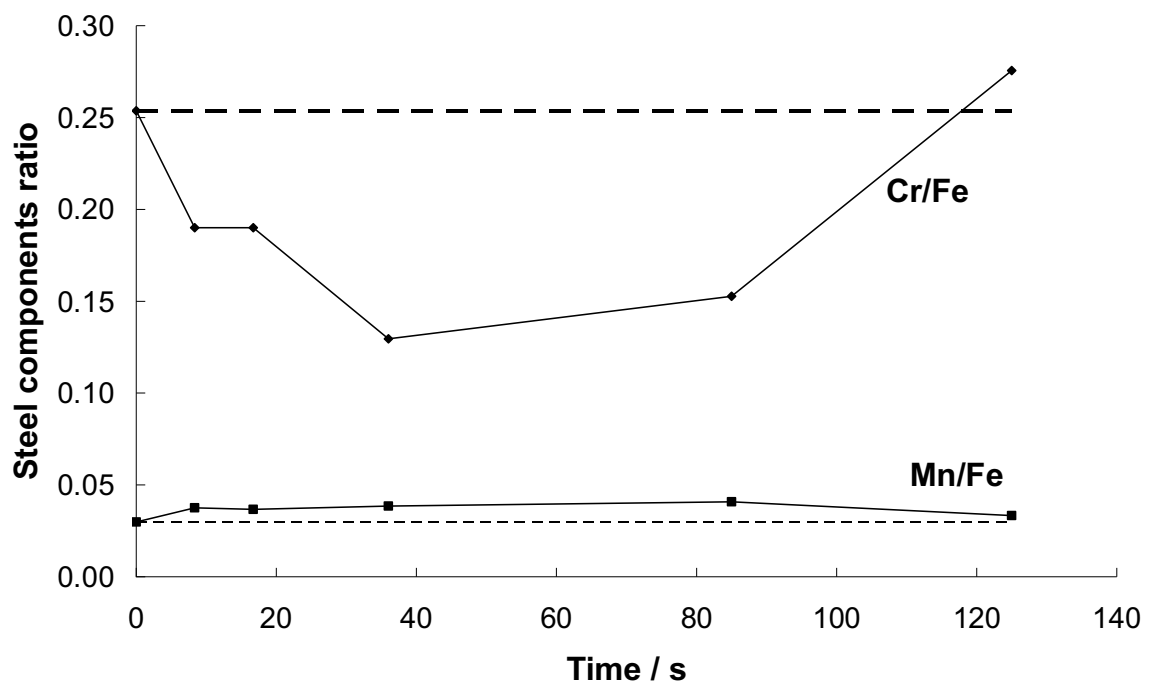

Figure 5. The change of steel component ratio in $\mathrm{NaCl}-\mathrm{KCl}$ melt during anodic dissolution of AISI $316 \mathrm{~L}$ (dashed lines - initial content ratio in steel).

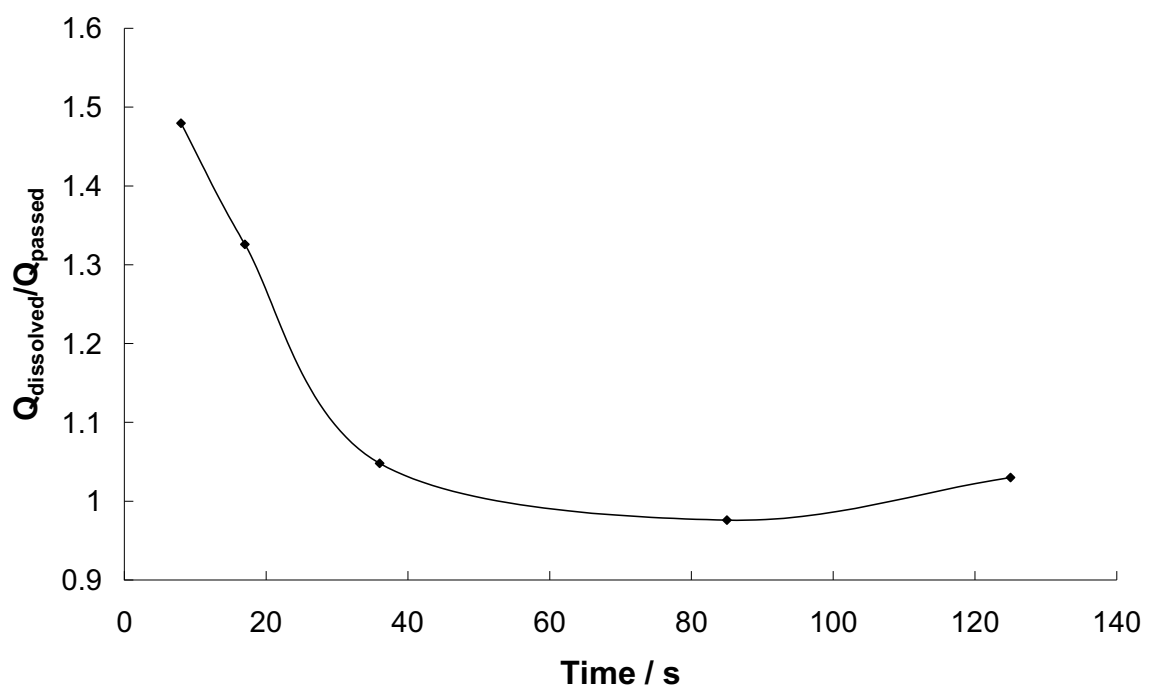

Figure 6. Time dependence of $\mathrm{Q}_{\text {dissolved }} / \mathrm{Q}_{\text {passed }}$ during anodic dissolution of AISI 316L stainless steel in $\mathrm{NaCl}-\mathrm{KCl}$ melt at $750{ }^{\circ} \mathrm{C}$. 


\section{Conclusions}

The products of anodic dissolution of $\mathrm{Fe}, \mathrm{Ni}, \mathrm{Cr}, \mathrm{Ti}, \mathrm{Mo}$ and $\mathrm{Mn}$ in $\mathrm{NaCl}-\mathrm{KCl}$ equimolar melt at $750{ }^{\circ} \mathrm{C}$ were studied using electronic absorption spectroscopy. It was shown, that combination of spectroscopic measurements of stainless steel anodic dissolution in alkali chloride melts with consecutive chemical analysis of quenched melts allows determining the sequence in which the steel components were dissolved. The iron, chromium and manganese species are the major products of the anodic dissolution of AISI 321, 316Ti and 316L type steels. Prolonged anodic dissolution of steel samples resulted in increasing chromium-to-iron content ratio in the melt. We conclude that under applied anodic potential the corrosion of stainless steels in molten chlorides is electrochemical in nature. At the initial period the exchange reaction between steel components and alkali metal cations takes place in parallel with the electrochemical process. It was found that titanium in steels forms strong carbonitride species that are not dissolved during anodic oxidation.

\section{References}

1. C. Edelcanu, J. G. Gibson and J. E. Meredith, J. Iron and Steel, 196, 1852 (1960).

2. S. I. Stepanov and E. B. Kachina-Pullo, J. Appl. Chem. (Russ), 35, 1852 (1962).

3. S. I. Stepanov and E. B. Kachina-Pullo, J. Appl. Chem. (Russ), 37, 379 (1964).

4. V. P. Kochergin, O. A. Putina, V. N. Devyatkin and E. T. Kanaeva, Protection of Metals, 11, 214 (1975).

5. I. N. Ozeryananya, N. A. Krasil'nikova, S. M. Perin, M. V. Smirnov and N. D. Shamanova, Protection of Metals, 14, 261 (1978).

6. D. O. Raleigh, J. T. White and C. A Ogden, J. Electrochem. Soc., 12, 1093 (1979).

7. H. Atmani and J. J. Rameau, Corros. Sci., 24, 279 (1984).

8. I. V. Oryshich, Met. Sci. and Heat Treat., 27, 218 (1985).

9. I. V. Oryshich and O. S. Kostyrko, Met. Sci. and Heat Treat., 27, 740 (1985).

10. H. Atmani and J. J. Rameau, Mater. Sci. Eng., 88, 247 (1987).

11. H. Atmani and J. J. Rameau, Corros. Sci,. 27, 35 (1987).

12. O. P. Penyagina, S. M. Perin, T. I. Manukhina and N. D. Shamanova, Rasplavy (Melts), Iss. 3, 70 (1994).

13. N. D. Shamanova, I. N. Ozeryannaya and V. G. Zyryanov, Protection of Metals, 33, 276 (1997).

14. N. D. Shamanova and N. O. Esina, Protection of Metals, 35, 43 (1999).

15. H. A. Abd El-Raman, A. Baraka and S. A. Abd El-Gwad, J. Appl. Electrochem., 29, 1205 (1999).

16. C. L. Zeng, W. Wang and W. T. Wu, Corros. Sci., 43, 787 (2001).

17. E. Yanase, K. Arai, I. Watanabe, M. Takahashic and Y. Daked, J. Synchrotron Rad., 8, 490 (2001).

18. Y. S. Li, Y. Niu and W. T. Wu, Mat. Sci. and Engin., A345, 64(2003).

19. B. P. Mohanty and D. A. Shores, Corros. Sci,. 46, 2909 (2004).

20. Y. S. Lia, M. Spiegela and S. Shimadab, Mat. Chem. and Phys., 93, 217 (2005).

21. W. M. Lu, T. J. Pan, K. Zhang and Y. Niu, Corros. Sci. 50, 1900 (2008).

22. V. A. Volkovich, B. D. Vasin, O. A. Tropin, D. A. Danilov and S. P. Raspopin, Russ. Metallurgy, Iss. 2, 150 (2010).

23. D. M. Gruen and R. L. McBeth, Pure Appl. Chem., 6, 23 (1963).

24. V. A. Volkovich, I. May, J. M. Charnock and B. Lewin, Phys. Chem. Chem. Phys., 
4, 5753 (2002).

25. B. D. Vasin, S. V. Maslov, V. A. Volkovich, I. B. Polovov, S. A. Kazakov and O. I. Rebrin, in Proc. 7-th Int. Symp. Molten salts Chem. and Techn., Vol. 1, p. 335, Toulouse (2005).

26. S. N. Flengas, T. R. Ingraham, J. Electrochem. Soc., 106, 714 (1959).

27. A. N. Baraboshkin, Electrocrystallization of Metals From Molten Salts, p. 58, Nauka, Moscow (1976) (in Russian).

28. A. P. Gulyaev, Metal Science, p. 376, Metallurgiya, Moscow (1966) (in Russian).

29. N. A. Krasil'nikova, I. N. Ozeryanaya, M. V.Smirnov and N. D.Shamanova, Protection of Metals, 10, 446 (1974).

30. I. N. Ozeryanaya, Metal Science and Heat Treatment, 27, 184 (1985). 